\title{
Елена Богданова
}

Michèle Lamont, Graziella Moraes Silva, Jessica S. Wellburn, Joshua Guetzkow, Nissim Mizrachi, Hanna Herzog, and Elisa Reis. Getting Respect: Responding to Stigma and Discrimination in the United States, Brazil, and Israel. Princeton, NJ: Princeton University Press, 2016. 377 pp. ISBN 978-0-6911-6707-7.

Елена Богданова - доцент Европейского университета в Санкт-Петербурге, научный сотрудник Центра независимых социологических исследований, доцент Российской Академии народного хозяйства и государственной службы при Президенте РФ. Адрес для переписки: ЦНСИ, а/я 193, Санкт-Петербург, 191040, Россия. bogdanova.nova@gmail.com.

Книга Мишель Ламонт и соавторов вписывается в ряд работ, проблематизирующих сосуществование социальных групп в условиях нарастающего культурного разнообразия современного общества. В работе предлагается нетривиальный подход к исследованию социального неравенства и социального исключения темнокожих в трех странах: США, Бразилии и Израиле. Авторы выбирают для исследования страны, в которых расовые проблемы стоят наиболее остро, и фокусируют внимание на наиболее социально исключенных группах: афроамериканцы в США, темнокожие бразильцы в Бразилии, палестинские арабы, эфиопские евреи, евреи североафриканского и средневосточного происхождения (мизрахим) в Израиле.

Эмпирическую базу исследования составляют почти 450 качественных глубинных интервью, проведенных в период 2007-2008 годов с обычными людьми, живущими в разных обстоятельствах, принадлежащими к различным культурам и обладающими разным доступом к культурным ресурсам. В каждом из кейсов эмпирические данные рассматриваются из перспективы основных социологических систем: раса, класс, занятость, гендер и возраст. Тем самым исследование делает вклад в социологический анализ социального признания и культурного гражданства, внося существенный социологический компонент в более философские тексты по этой теме.

Случай каждой из стран рассматривается как отдельный кейс, сопровождающийся глубоким социально-культурным и историческим анализом национального контекста и соотнесением его с глобальным контекстом. В случае, например, США значимым оказывается дискурс об американской мечте, который оказал существенное влияние на всю систему стратификации и на определение места темнокожих в американском обществе. В Бразилии столь же важна концепция бразильской расовой демократии, а в Израиле сложившийся синтез сионизма и прав человека. В Израиле, в отличие от США и Бразилии, никогда не было рабства. Все это влияет на то, как группы темнокожих встроены в национальную мифологию стран, и на то, как фактор цвета кожи функционирует в качестве драйвера исключения внутри национального контекста. Стигматизация, согласно авторам, не обя- 
зательно ведет к дискриминации. Только при наличии и стигматизации, и дискриминации можно говорить об этнорасовом исключении.

Исследование выполнено в традиции французской прагматической социологии. Авторы подбирают методологические инструменты, сознательно исключая такую деталь, как институциональные основания. Взамен они пытаются реконструировать понимание стигмы и дискриминации из нарративов самих людей, переживающих негативное отношение со стороны общества в различных культурных контекстах. Вместо того чтобы сопоставлять взгляды людей с институциональными условиями и выявлять, насколько те и другие расходятся между собой (Boltanski 2008), авторы предлагают принять всерьез нарративы социальных акторов. Занимая конструктивистские позиции, они утверждают, что нарративы управляют действиями (Somers 1994), направляют и ограничивают их (Polletta et al. 2011). В предложенном подходе понимание качества общества включает не только набор характеристик, основанных на распределении и благосостоянии, но также и аспекты признания, голоса и включенности в социальную жизнь. Хиршмановские exit voice and loyalty (Hirschman 1970) принимают разные формы в разных контекстах, и авторы исследования пытаются ухватить их, изучая, как группы темнокожих в разных странах переживают этнорасовое исключение и как отвечают на него.

Связующим элементом всего исследования является моральная конвенция уважения и признания. В качестве ключа, открывающего причины, механизмы и последствия социального исключения, рассматриваются нарративы информантов об опыте переживания обид, неуважения и посягательства на признаваемые ими ценности (assault on worth). Рассказы информантов об отказах, сниженном качестве обслуживания, злых шутках, двойных стандартах, исключении из неформальных сетей, физических нападениях и угрозах - материал, с которым работают авторы. Феноменологический анализ опыта, реконструированного на основе ответов информантов, представляет этнорасовое исключение в каждом из национальных контекстов на трех уровнях: как микрофеномен переживания индивидуального опыта, как феномен среднего уровня в форме культурных репертуаров и сплоченности этнических групп и как социетальные характеристики и национальную историю на макроуровне.

Пожалуй, даже более важное место, чем опыту переживания неуважения, авторы отводят реакции, которую продуцируют темнокожие в ответ на обиды. Из анализа всех кейсов выводятся основные формы ответов: конфронтация, развитие самообладания и сознательное избегание какого-либо ответа, самосовершенствование и демонстрация конкурентоспособности, самоизоляция и игнорирование негативных проявлений со стороны общества. Анализ показывает, что в разных национальных контекстах преобладают разные стратегии ответа на обиды: коллективные или индивидуальные, основанные на классовой идентичности или же на сильной идентификации с этнической группой. Так, например, афроамериканцы в США и арабские палестинцы в Израиле обладают сильным чувством принадлежности к своим этническим группам, и мобилизация их легче происходит на уровне этнических сообществ. Напротив, высокий уровень национальной 
идентичности бразильцев и евреев-мизрахим заставляет их отдавать предпочтение гражданским требованиям перераспределения благ вместо актуализации этнических идентичностей.

Методологический инструмент, созданный авторами книги, обладает большим потенциалом применения для исследования механизмов и последствий социального исключения самых разнообразных групп в различных социокультурных контекстах. В современном мире сложных перекрестных идентичностей, мобильностей и конфликтного соседства моральная конвенция признания и уважения срабатывает как известное основание социальной стратификации, применимое для сравнительных социологических, культурологических и философских исследований. Однако сравнение, представленное в книге, порождает несколько вопросов. Центральная конвенция уважения и признания используется авторами как универсальная, обладающая схожими смыслом и ценностью во всех трех кейсах. Такое применение кажется более согласующимся с концепцией структурного функционализма. Представляется, что феноменологический подход, последовательно применяемый авторами книги, требует контекстуализации самого понятия уважения в каждом из рассматриваемых случаев. Можно спорить о том, насколько одинаково оно понимается в исследуемых обществах. В условиях американского общества оно прочно связано генетически с понятиями человеческого достоинства и прав человека. Происходит ли это схожим образом в других рассматриваемых национальных контекстах?

В книге представлено три кейса, и в связи с этим возникает еще один вопрос. Отказываясь от привычных институциональных «костылей», авторы утрачивают лекала, с которыми можно было бы соотносить нарративы, полученные в ходе интервью. Соответственно, авторы пытаются настроить линзы исследования другими способами. Базой выстраивания анализа становится культура, история, культурные и исторические коды определенного национального контекста. Однако и их необходимо соотнести с каким-то фоном, чтобы рассмотреть детали. Таким фоном становятся другие национальные контексты. Сравнение делает результаты исследования более яркими и доказательными, но возможно ли применение предложенной методологии вне межкультурного сравнения?

\section{СПИСОК ЛИТЕРАТУРЫ}

Boltanski, Luc. 2008. “Domination Revisited: From the French Critical Sociology of the 1970s to Present-Day Pragmatic Sociology." Graduate Faculty Philosophy Journal 29(1):27-70.

Hirschman, Albert. 1970. Exit, Voice, and Loyalty: Responses to Decline in Firms, Organizations, and States. Cambridge, MA: Harvard University Press.

Polletta, Francesca, Pang Ching Bobby Chen, Bath Gharrity Gardner, and Alice Motes. 2011. “The Sociology of Storytelling." Annual Review of Sociology 37:109-130.

Somers, Margaret R. 1994. "The Narrative Constitution of Identity: A Relational and Network Approach." Theory and Society 23(5):605-649. 